\title{
VIII
}

\section{THE DEATH OF AGASSIZ-HIS PERSONALITY ${ }^{1}$}

T $N$ later years the robust constitution and herculean frame of Agassiz showed the effects of his extraordinary and multifarious labors, for it must be confessed that he was not careful of his bodily welfare. In the year 1869 he suffered a temporary breakdown of a very threatening sort, and for months was in seclusion, forbidden by his medical advisers even to think. His own wise efforts, and a quiet spring passed in the village of Deerfield, Connecticut, brought about his recovery, so that three years of activity were

1 The materials for this sketch are drawn from several sources-chiefly the Life by Marcou (which I have used vith some caution) and the Life by Mrs. Agassiz. I had wished to preserve the words of Marcou throughout (with judicious omissions), but this wish was defeated by certain persons who, for reasons unknown to me, have the power to prevent the use of adequate quotations from him. I have followed him where I had no other guide, and no ground for suspecting him of bias. The composition, and to some extent the interpretation of the facts, are my own. 
yet to be vouchsafed him. But the strain of his lectures, of his correspondence, of his labors at and for the Museum, was perilous. On the second of December, 1873, he gave a lecture, his last, on 'The Structural Growth of Domestic Animals,' before the Massachusetts Board of Agriculture at Fitchburg. On the third he dined with friends; on the fifth he was present at a family gathering-and smoked cigars, defying the orders of his physician. But the end was not far off. He spoke of a dimness of sight; he complained of feeling 'strangely asleep.' On the morning of the sixth he went as usual to the Museum, but with a sense of great weariness he shortly returned to his room, where he lay down, never to depart from it alive. The disease was a paralysis of the organs of respiration, beginning with the larynx. He had every care from his friends Dr. Brown-Séquard, who immediately came from New York, and Dr. Morrill Wyman; and the last few days of his life were passed, not in great suffering, with his loving family around him. Nothing, however, could arrest the progress of the malady.

[50] 
Agassiz, it is said, had been afraid of softening of the brain, and of a long and painful illness like that which preceded the death of his friend Professor Bache; it had been his hope that he might rather go quickly. Yet it was not easy for him to think of dying, when his imagination teemed with projects, and when the two main visions of his life were on the point of being fully accomplished, in the great Museum and the Anderson School of Natural History on the island of Penikese. Stricken though he was, he clung to life, nor did he give up all hope of recovery until the last day. Still there was a change of demeanor, for the aims of his career as a scientist were now less obtrusive in his mind than thoughts of his family. And with the arrival of Dr. BrownSéquard he resumed the language of his youth, so that his last words were uttered in French. In the closing hours, when at length all hope was abandoned, he was more than once heard to say: 'Tout est fini.' On the eighth day, when death itself was approaching, his family and friends - among these, Pourtalès - withdrew to an adjoining room, keeping watch over the 
patient through the open door. While Pourtalès was standing there in his turn, not long after ten o'clock at night, Agassiz lifted himself up in bed, and said with emphasis: 'Le jeu est fini.' Then, sinking back, he passed away. 'The play is done. Plaudite.' For Agassiz life was a game, full of motion, crowded with incident. He could not understand the complaint of those who found time hanging heavily upon their hands, and who sought ways of killing it. He, who had 'no time for making money,' would gladly have borrowed an extra life or two for study and teaching. From the outset he had unwavering confidence in himself. He would be 'the first naturalist of his time, a good citizen, a good son, beloved of those who knew him.' He was not to follow others; he would lead in his own path, which should be the right path, and others should follow him.

Agassiz was somewhat above the average in height. His body was well formed, his shoulders broad and square, his figure powerful, firmly set upon rather small feet that served him well in walking and climbing. With a [52 ] 
quick, elastic step, he was an excellent pedestrian, and quite at home in the mountains. As a boy he became proficient in swimming and in the management of boats. To bodily fear he was a stranger. His hands were large and shapely, and very skilful. Never a finished draughtsman, he was none the less expert in representing, with swift, sure strokes, the essential structure of the object he wished to recall. or explain. He was deft, too, with the dissecting-knife and the microscope, and with the geologist's hammer. His neck (the weak part, as his fatal illness showed) was rather short; his head was fine and large. In later years his hair, of a chestnut color, deserted his brow, but he wore it full at the sides and back, and this, with the side-whiskers of the day, tended to conceal his ears. The head itself was admirable, the forehead high and broad, the chin shapely, the countenance frank and open. The mouth was wide, the lips full and smiling, the expression as a whole altogether amiable and intelligent. His aquiline nose, with welldeveloped nostrils, sharply set off by the oblique lines on either side, helped to give him 
an air of sagacity. Butitwas themagnificent, fascinating eyes, young, kindly, and searching, that above all gave life to that animated countenance. To those eyes nothing was commonplace. ${ }^{1}$

Agassiz spoke French with a slight drawl characteristic of the section of Switzerland in which he was born. When he came to America in 1846, he rapidly acquired a command of English, and he eventually wrote and spoke the language with great facility, though his speech never ceased to betray his foreign origin. ${ }^{2}$

1 Compare Clara Conant Gilson, 'Agassiz at Cambridge,' in Frank Leslie's Popular Monthly, December, 1891: 'He was a man of fine figure and striking appearance, not too much of the embonpoint, not too tall, but just tall enough to constitute a finely developed physique. His head was grand, of perfect intellectual shape, and commanded your admiration as you gazed. He was but slightly bald, his hair was of a beautiful brown, soft and fine, and fell lovingly over the collar of his coat. His face was of well-rounded contour, with a large, expressive mouth, and features indicative of great character and decision. His eyes were the feature of his face, par excellence. They were of a beautiful bright brown, full of tenderness, of meaning and earnestness-a liquid brown eye, that would moisten with tears of emotion as thoughts of his Creator came rushing to mind, while he traced His footsteps in the sciences he studied. His eyes mirrored his soul. I think there was never but one pair of eyes such as Professor Louis Agassiz's.'

2 See Clara Conant Gilson, in the article just cited: He had

[54] 
With his superabundant physical, mental, and emotional energy, he was a natural orator; he was fond of an audience, and gratified by applause. No one ever possessed a greater talent for making natural science popular; even when his discourse became highly technical, his auditors hung upon his words. His method of exposition was very clear and simple. He studiously avoided the error of dragging the listener through all the processes by which the speaker has arrived at a particular truth, and quickly came to the point. In lecturing, his personal magnetism counted for much; he readily communicated his enthusiasm to others.

He was easily moved to tears or to laughter. In his earlier life he was seldom angry, or seldom showed it, but otherwise made no attempt to hide his feelings, being a perfect

a few striking peculiarities of pronunciation, one or two of which cling to me with great pertinacity even now. One, in particular, is fresh in my memory. For example, the words respiratory and perspiratory he would accent on the third syllable-rat; and, bless me, if to this day I don't have to think twice before I am sure which is right! This shows what indelible impressions his words left upon his pupils. 
child of nature. Later he became less demonstrative, save when he was angry. In the last twenty years of his life he not infrequently lost his temper, though he would not utterly forget what he was saying; and, however heated the discussion might become, he never ceased to be a gentleman. Neither indecency nor aught approaching thereto ever issued from his lips. As a youth in Switzerland, during his life as a student, and even when he was a teacher at Neuchâtel, he was fond of singing, and he liked to yodel after the fashion of the Swiss and Tyrolese mountaineers, but he gave this up when he came to America.

Here his recreations were mostly social. He was the friend of Longfellow, Lowell, and Whittier; he was the friend of laborers and fishermen. In society he liked to encounter men of wealth and influence, for he had by nature, and also learned from Alexander von Humboldt, some of the arts of the courtier. 'It would be difficult,' says Dr. Charles D. Walcott," 'to measure his influence in the way of causing men of political and commercial

${ }^{1}$ Smithsonian Miscellaneous Collections 50. 217 (1908).

[56] 
power to realize that the support of scientific research, and the diffusion of knowledge thereby gained, depend largely on them.' In other natural scientists he was prone to discover too much self-satisfaction, and too much personal curiosity, against which he hardly knew how to protect himself. But with the group of younger scientists he himself developed, though now and then one or another grew mutinous, he was, during most of the time, on the best of terms. His own early schooling in the classics gave him a relish for scholars, and he was pleased with the company of historians and lawyers. For military men he did not care, but he liked naval officers and sea-captains. $\mathrm{He}$ paid little attention to matters of dress, certainly as regards his own person. He was gratified by the marks of distinction conferred upon him at home and abroad, but took little subsequent thought of the ribbons, badges, and diplomas, keeping them, but not very carefully, and never making a parade of them.

Eloquent as a lecturer, he was also brilliant and persuasive in conversation, being, in appearance at least, quite unreserved, and open 
in his attempt to capture the good will of his auditor. However, if there was no covert artifice, there was at all events the native shrewdness of the Swiss peasant to reckon with, and doubtless the subtlety of genius-which will not, or cannot, always reveal itself in full. In his later years, accordingly, though his winning manners and his desire that you should completely display your thought to him might lead you to suppose him utterly open with you, you might in the end discover that you had not fathomed his soul, that there was that in him which could not be taken captive, and that there might be a silent invincible rejection on his part of something within you which was foreign to him.

In Agassiz the theoretical and the practical life were well balanced. He was both a visionary and a man capable of bringing his visions to pass. No philosophical conception was too general for him, and no detail of observation or inference too small. No fact could appear too slight for his intense and comprehensive scrutiny, and his memory for minute resemblances and differences was vast; yet the enduring [58] 
quality of his work arose from his sense of order, and from the soundness and rigor of his principles. He possessed not only physical, but intellectual and moral courage. In the face of hardship or difficulty he was undaunted, ever energetic at the moment, ever hoping for better times. His power of working was enormous, for he made virtually no false motions, but proceeded silently, swiftly, with no apparent effort, and for long periods without interruption.

Much has been said by his friends of the depth and sincerity of his sentiments in point of religion. But he had little sympathy with clergymen, or with the definite forms in which the religious experience of man has expressed itself-though these forms are in their essence and development not unlike the natural forms which he so reverently studied. One who knew him well affirms that in early manhood Agassiz, if not precisely a materialist, was at all events a sceptic; but his later studies, with mature reflection, led him to believe in a Divine Creator. The external universe became to him the language in which the Divine Being 
conveys his ideas to man, and natural history the discipline by which men interpret that language. Thus he says, in the Essay on Classification: 'To me it appears indisputable that this order and arrangement of our studies are based upon the natural, primitive relations of animal life-those systems, to which we have given the names of the great leaders of our science who first proposed them, being in truth but translations into human language of the thoughts of the Creator. And if this is indeed so, do we not find in this adaptability of the human intellect to the facts of creation, by which we become instinctively, and, as I have said, unconsciously, the translators of the thoughts of God, the most conclusive proof of our affinity with the Divine mind? And is not this intellectual and spiritual connection with the Almighty worthy of our deepest consideration? If there is any truth in the belief that man is made in the image of God, it is surely not amiss for the philosopher to endeavor, by the study of his own mental operations, to approximate the workings of the Divine Reason, learning from the nature of his own mind better [60] 
to understand the Infinite Intellect from which it is derived. Such a suggestion may, at first sight, appear irreverent. But who is the truly humble? He who, penetrating into the secrets of creation, arranges them under a formula, which he proudly calls his scientific system? or he who in the same pursuit recognizes his glorious affinity with the Creator, and in deepest gratitude for so sublime a birthright strives to be the faithful interpreter of that Divine Intellect with whom he is permitted, nay, with whom he is intended, according to the laws of his being, to enter into communion?' 1 Herein we may discern the secret of his power as a teacher.

'Agassiz's influence on methods of teaching in our community,' said Professor James, 'was prompt and decisive-all the more that it struck people's imagination by its very excess. The good old way of committing printed abstractions to memory never seems to have received such a shock as it encountered at his hands. There is probably no public school teacher now [1896] in New England who will

${ }^{1}$ Essay on Classification (1859), pp. 9-10. 
not tell you how Agassiz used to lock a student up in a room full of turtle-shells, or lobstershells, or oyster-shells, without a book or a word to help him, and not let him out till he had discovered all the truths which the objects contained. Some found the truths after weeks and months of lonely sorrow; others never found them. Those who found them were already made into naturalists thereby - the failures were blotted from the book of honor and of life. "Go to nature; take the facts into your own hands; look, and see for yourself!"these were the maxims which Agassiz preached wherever he went, and their effect upon pedagogy was electric. ... While on the Thayer expedition [to Brazil, in 1865], I remember that I of ten put questions to him about the facts of our new tropical habitat, but I doubt if he ever answered one of these questions of mine outright. He always said: "There, you see you have a definite problem. Go and look, and find the answer for yourself."

1 William James, Louis Agassiz, Words Spoken . . at the Reception of the American Society of Naturalists ... [Dec. 30, 1896]. Pp. 9, 10. Cambridge, 1897.

[62] 